\title{
Analysis of marketing strategy at setia stores using ahp, clustering, and ar-mba method
}

\author{
Faisal Ibrahim*, Bagas Swardhana Putra, Fariza Halidatsani Azhra, Najib \\ Fadhlurrohman
}

Department of Industrial Engineering, Universitas Islam Indonesia, Yogyakarta, Indonesia

faisal.ibrahim47@gmail.com; 17522268@students.uii.ac.id; farizazhra@gmail.com; 17522107@students.uii.ac.id

*Corresponding Author: faisal.ibrahim47@gmail.com

\section{ARTICLE INFO}

\section{Keywords}

Analytical Hierarchy

Process;

Association rules; Market

Basket Analysis;

K-Means Clustering.

\section{Article History}

Received:

July 1, 2021

Revised:

August 20, 2021

Accepted:

August 30, 2021

Available online:

August 31, 2021

\section{ABSTRACT}

A company can survive and thrive when the strategies and processes applied in its business are correct. One of the processes in determining strategy in decision making. The owner of Setia Store has difficulty in choosing a marketing strategy. The product layout shows this in the Setia Store, which confuses customers. Setia Store also rarely offers a promotion, making it difficult to compete with competitors. This study aims to help Setia Store increase sales by determining the right marketing strategy. To determine the right marketing strategy, there are three methods. First, Analytical Hierarchy Process (AHP) is used to find customer priorities. Second, clustering is used to find potential marketing targets that have similar characteristics to the results of the AHP method. Third, Association Rule - Market Basket Analysis (AR-MBA) is used to find the best rules for product marketing strategy. The first method shows that the housewives $(E V=0.6270)$ are Setia Store's priority customers from the three methods. Second, cluster 3 (which has three characteristics in common) is a very potential target market. Third, the best rule is to buy products from departments 2 and 3 (Confidence 60\%, Support 12\%). From these results, the right marketing strategy is to create a buy 1 get 1 promo banner or label for products that are rarely purchased, such as household appliances. Then, create a catalog by bringing together frequently purchased products such as spices and food ingredients. Finally, improve the layout by bringing the departmental shelves closer to frequently purchased products.

\section{Introduction}

The rapid development of globalization makes business in Indonesia require a company continue to adapt in all situations and conditions. To survive and thrive in these conditions, companies need to develop the right strategy and continue to grow in business competition 
(Husna, 2019). One of the factors that influence the company's success in business competition is at the time of decision making.

The factor that can affect the speed of decision-making of a company is information technology. This is because information technology can provide convenience for humans in carrying out their work activities (Butar-Butar, et al., 2020). Information technology can be used to process or produce correct and ready-to-use information to assist a person or group in making the right decision. Therefore, to find out what decision to make, a decision-maker must take advantage of company data or what is commonly called data mining.

The decision analysis process carried out by decision-makers, such as managers, requires criteria before choosing various alternatives. These criteria describe the problem definition in a concrete form to serve as a target to be achieved. These criteria will be analyzed to get a standard measurement, which will compare the various alternatives obtained.

Today the industrial world is snowballing. This development not only occurs in large-scale industries but also in small-scale industries, such as SMEs (Small and Medium Enterprises). Based on the Decree of the President of the Republic of Indonesia Number 99 of 1998, SMEs are "people's economic activities as an inseparable part of the business world that have a strategic position, potential and role in realizing a more balanced national economic structure and equitable development-based on economic democracy" (President Decision, 1998). SMEs are an essential part of the economy because of their role in increasing economic growth in Indonesia (Nasution \& Lubis, 2018). In this study, the object of research used is Setia Store as an SME. Setia Store is a local minimarket that sells various household needs, ranging from cooking utensils, necessities, toiletries, etc.

The reason this research chooses Setia Store is that the marketing strategy used is not good. It can be seen from the store layout, which confuses customers and rarely holds promotions so that Setia Store finds it challenging to compete with competitors in the vicinity. Second, the lack of expertise of the Setia Store owner in making decisions in the form of the right marketing strategy for his store. Third, this store is a local minimarket that must be supported to increase sales and improve the regional economy. Therefore, to determine the right marketing strategy for Setia Store, we will use three data processing methods. First, the analytical hierarchy process (AHP) is used to find Setia Store's potential customers. Second, clustering is used to find potential target markets that have similar characteristics with the results of the AHP method. Finally, association rules \& market basket analysis (AR-MBA) were used to find the best practices for product marketing.

The purpose of this research is to help Setia Store owners to determine the right marketing strategy. Second, help increase sales from Setia Store and improve the regional economy. Third, contribute to creating new research references regarding marketing strategy analysis. Finally, it is hoped that this research will positively impact small retail owners in the form of knowledge and awareness of the importance of determining the right marketing strategy.

\section{Literature Review}

The primary basis of this literature review is the practice of using the Analytical Hierarchy Process (AHP), Clustering, and Association Rule \& Market Basket Analysis (AR-MBA) methods to determine the right marketing strategy. Marketing strategy is a planning process carried out by 
companies to market and introduce products and services offered to consumers to achieve company goals with all the obstacles and risks faced (Riandi, 2021). Marketing can be influenced by various factors, such as social, cultural, political, economic, and managerial factors (Cahyono, 2016). Based on this, the marketing strategy has a vital role in maintaining business continuity and growth in the long term (Fawaid, et al., 2016). In addition, the marketing strategy also provides direction for companies related to market segmentation, market identification, marketing mix, and positioning (Atmoko, 2018).

Research conducted by Sari and Nurhadi said that the AHP method could be used to measure the attractiveness of market segmentation with input data derived from interviews (Sari \& Nurhadi, 2019). AHP can also determine the priority level of the variables used to determine which variables can be prioritized by the company (Nurainun \& Malva, 2016). Research conducted by Permata and others using the AHP method combined with SWOT analysis resulted in twelve strategies to determine the most appropriate marketing strategy for the company (Permata, et al., 2019).

Concerning marketing strategy, the clustering method can also be used to help determine the right marketing strategy. Research conducted by Hakim found that the K-Means cluster method can be used to determine the plan of stocking goods so that there is no accumulation through three criteria: very selling, selling well, and not selling well (Hakim, 2020). According to consumer shopping habits, another study said that the K-Means clustering method could also produce a product layout model in supermarkets according to consumer shopping habits (Lestari, 2019). Another research conducted by Anjassari on customer buying patterns using the Market Basked Analysis method can help regulate the relationship between products to get the correct arrangement of goods placement (Anjassari, 2018).

Based on the search results related to previous research, it was found that the research conducted had a variety of research methods used to determine the right marketing strategy. A comparison was found that previous studies only used one or two research methods. For example, they used one or two combinations of AHP, cluster, or AR-MBA, where the results will undoubtedly be different and less accurate. By combining the three methods in a related manner, this research is expected to produce a more detailed and precise analysis to determine the right marketing strategy for the company.

\section{Research Methodology}

\subsection{Method of Collecting Data}

Figure 1 shows the data collection methods used in this study. The data required is 50 transaction data or 50 offline store receipts. Data or receipts that can be utilized contain product items from two different product departments in Setia Store. In this study, an online questionnaire (google form) will be used, distributed to Setia Store customers to collect transaction data. The survey results obtained 63 respondents consisting of $46 \%$ housewives, $41.3 \%$ students, and $12.7 \%$ employees. The data obtained is then filtered by sorting out whether there are missing, noisy, and inconsistent data so that only 58 data can be used. This is means that this research data has 8 data backups. The filtered data will be processed, transformed, and obtained the pattern to obtain data knowledge. 


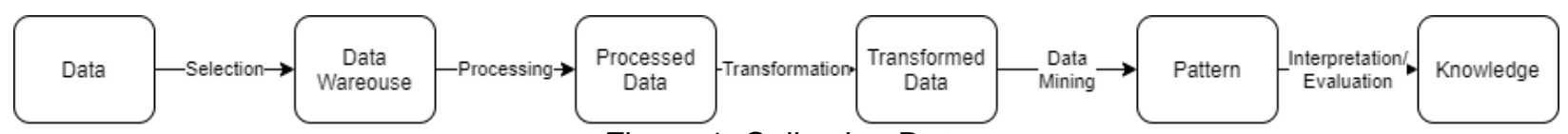

Figure 1. Collecting Data

In addition to transaction data from respondents, data from the Setia Store layout was also obtained. The store layout can be seen in Figure 2 below. Number 1 is the household appliances department. Then, number 2 shows the kitchen spice department. Next, number 3 presents the groceries department, and number 4 is the sachet beverage department. Then, number 5 is the snack department. Next, the milk and yogurt department is presented in number 6 . Then, number 7 indicates the flavored beverage and mineral water department. After that, number 8 is the grooming and laundry soap department. Then, number 9 is the grooming products department, and number 10 is the women's and baby supplies department. Next, number 11 is the gas and gallon mineral water department, and number 12 is the cigarette supplies department.

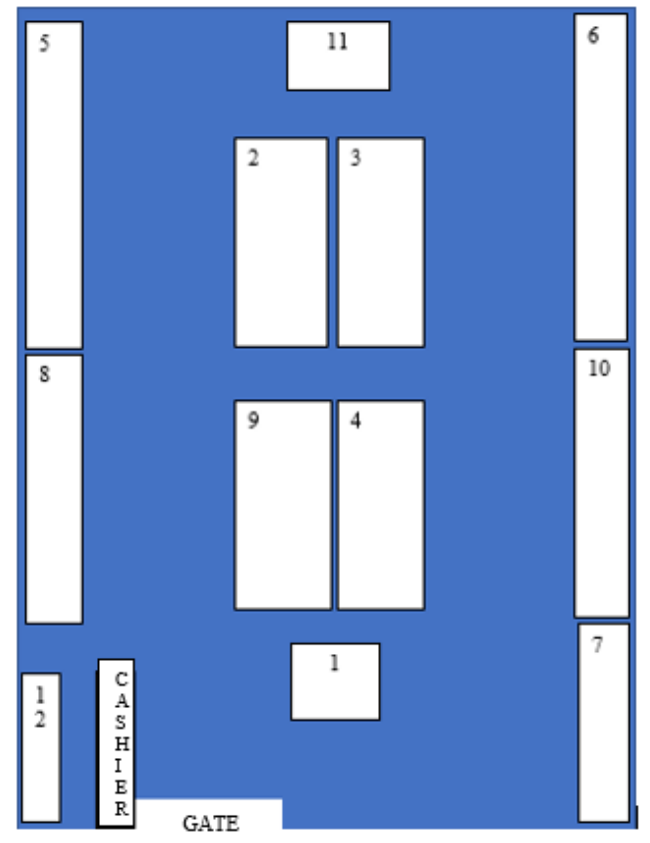

Figure 2. Initial Layout

\subsection{Research Location}

This research is in Setia Store, located on Jalan Army Student Km.10, Sariharjo, Ngaglik, Sleman, Yogyakarta. The researcher chose Setia Store because the owner of the Setia Store had difficulty determining the right marketing strategy for his store. It can be seen from the store layout, which confuses customers and rarely holds promotions so that Setia Store difficult to compete with competitors in the vicinity. Then, the expertise of the Setia Store owner is lacking in making decisions in the form of the right marketing strategy for his store finally, because this store is a local minimarket that must be supported to improve the regional economy. 


\subsection{Research Instruments}

In this research, the instruments used are as follows:

a. Draw.io is a tool for creating Setia Store layouts.

b. Google Form is a tool to create online questionnaires and collect transaction data from Setia Store customers.

c. Software Ms. Excel is software for processing AHP method data.

d. Software SPSS is software for processing Clustering method data.

e. Software Rapid Miner is software for processing AR-MBA method data.

\subsection{Data Processing}

In this study, the data processing methods used are as follows:

\section{a. Decision Analysis}

Analytical Hierarchy Process (AHP), used to find the main priority of Setia Store customers. AHP is a decision-making method developed by Thomas L. Saaty by describing multifactor or multicriteria problems into a hierarchy (Munthafa \& Mubarok, 2017). This method is considered the most inclusive in decision-making with several criteria because it formulates the issue as a hierarchy (Taherdoost, 2017). The AHP method also combines qualitative and quantitative factors to arrive at one assessment (Alsamaray, 2017). Hierarchy can be defined as a representation of a complex problem in a multilevel structure consisting of the first level, namely objectives, followed by the level of factors, criteria, sub-criteria, and so on until the last level of alternatives. The basic concept of AHP is the use of pairwise comparison metrics to generate relative weights between criteria and between other options, which are obtained from comparisons between criteria in terms of their importance (Mohammad, 2018). Pairwise comparison metrics are needed to get a decision based on a predefined hierarchy. Processing the pairwise comparison metric data is obtaining the eigenvalues of the factors and their evaluation. So that through this evaluation, the order and ranking can be known to get the best results (Rosiska \& Harman, 2019).

\section{b. Data Mining}

Clustering is used to find potential target markets that have similar characteristics with the results of the AHP method. Cluster analysis can be divided into several bases, including hierarchical, partition, grid, density, and model-based methods (Ji, et al., 2019). The purpose of this analysis is to classify data objects into two categories. The first is objects with the same characteristics in the same cluster, and the second is objects with different characteristics from other objects in other clusters (Nagari \& Inayati, 2020). Many methods can be used for cluster analysis, such as K-Means, Fuzzy C-Means Clustering, Self Organizing Maps, etc.

K-Means is a clustering analysis method that, in its implementation, uses data mining in the process of grouping the data (Bastian, et al., 2018). K-Means has many advantages, such as easy implementation, simple mathematical ideas, and fast convergence in partition-based clustering algorithms (Xiao-yu, et al., 2017). The purpose of this K-Means method is to determine the number of clusters to be formed, after which the first variable in the cluster can be selected to be used as the midpoint of the cluster in the formation process. Repeated steps will continue to 
be carried out until data stability can be achieved so that no data objects will move (Nagari \& Inayati, 2020).

Association Rule \& Market Basket Analysis is used to find the best rules for product marketing. The results of this AR-MBA data processing can be used as a reference to determine the improvement of Setia Store's marketing strategy. Association rule is a technique in data mining that is useful for finding associative relationships from a group of data sets (Alfiqra \& Khasanah, 2020). Association rules can also be used to determine effective strategic management in strategic management (Shi, et al., 2019). Market basket analysis helps analyze the relationship between all items included in the transaction to obtain information to benefit marketing strategy so that opportunities to increase sales of items simultaneously can be done (Halim, et al., 2017). In addition, market basket analysis can also be used to determine and predict customer behavior patterns when shopping based on spending habits from previous customers (Tatiana \& Mikhail, 2018).

Support and confidence are essential parameters in the association rule. Support eliminates information on the relationship between items with a slight chance of occurrence because it is considered meaningless. Meanwhile, confidence measures how strong the conclusions are obtained from the results of processing calculations (Halim, et al., 2017).

\subsection{Research Flow}

Figure 3 below shows the research flow employed in this study. The flow of this research starts from a site survey to see if the location has a problem or not. Second, identify issues in the surveyed areas. Third, if there is a problem, it can proceed to the following, determining the decision analysis method and data mining. Fourth, collect data. Fifth, perform data processingsixth, presenting the results and discussion. Finally, provide conclusions and suggestions in the form of marketing strategies. The following is the research flow used in this study.

\section{Result and Discussion}

\subsection{Analytical Hierarchy Process (AHP)}

From the calculation results of the AHP method in Figure 4 below, it can be seen that the value of the Eugen vector for students is 0.2923 , housewives are 0.6270 , and employees are 0.0807 . The Eugen vector value is used to determine the priority of Setia Store customers. The order of priority for Setia Store customers is housewives, students, and employees. Based on these results, the housewives are the main priority for Setia Store customers. These results will serve as a reference for Setia Stores to determine the appropriate treatment for their priority customers. This is because each type of work has different characteristics so that the shop's treatment of customers cannot be the same.

For information, the use of criteria and determination of weights in this method is based on the results of interviews with the owner of the Setia Store and the researchers' assumptions based on the percentage of types of work from the effects of an online questionnaire survey through google forms. 


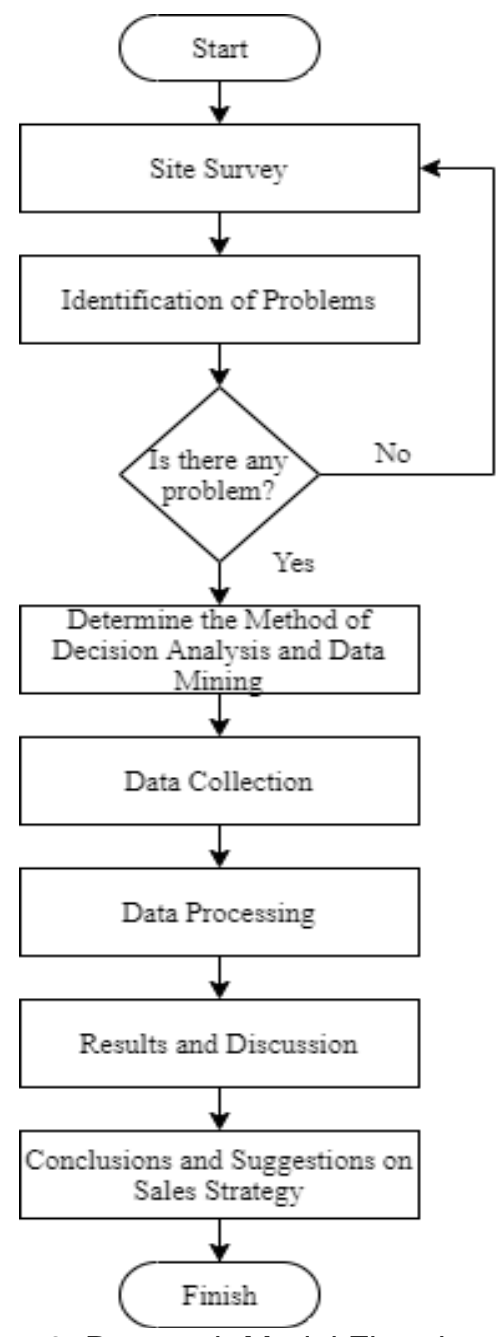

Figure 3. Research Model Flowchart

\begin{tabular}{|c|c|c|c|c|c|c|}
\hline Criteria & Student & Housewife & Employee & Student & Housewife & Employee \\
\hline Student & 1 & $1 / 3$ & 5 & 0.2381 & 0.2222 & 0.4167 \\
\hline Housewife & 3 & 1 & 6 & 0.7143 & 0.6667 & 0.5000 \\
\hline Employee & $1 / 5$ & $1 / 6$ & 1 & 0.0476 & 0.1111 & 0.0833 \\
\hline Total & 4.2 & $11 / 2$ & 12 & 1 & 1 & 1 \\
\hline
\end{tabular}

\begin{tabular}{|c|c|c|c|c|c|c|c|}
\hline 1 & 2 & 3 & $4=3 / 2$ & $5=$ Sum $4 /$ Sum 1 & $6=(5-\operatorname{Sum} 1) /(\operatorname{Sum} 1-1)$ & 7 & $8=6 / 7$ \\
\hline $\begin{array}{l}\text { Total } \\
\text { Weight } \\
\text { Matrix }\end{array}$ & $\begin{array}{l}\text { Eugen } \\
\text { Vector }\end{array}$ & $\begin{array}{c}\text { Matrix } \\
\text { Multiplication }\end{array}$ & $\begin{array}{l}\text { Eugen } \\
\text { Value }\end{array}$ & A maks & a & IR & CR \\
\hline 0.8770 & 0.2923 & 0.9048 & 3.0950 & \multirow{4}{*}{3.0951} & \multirow{4}{*}{0.0475} & \multirow{4}{*}{0.5800} & \multirow{4}{*}{0.0821} \\
\hline 1.8810 & 0.6270 & 1.9881 & 3.1709 & & & & \\
\hline 0.2421 & 0.0807 & 0.2437 & 3.0197 & & & & \\
\hline 3 & 1 & 3.136508 & 9.285581 & & & & \\
\hline
\end{tabular}

Figure 4. AHP Output 


\subsection{Clustering}

Figure 5 is obtained from the results of data processing using the K-Means method. These results show the number of members from each cluster. Cluster 1 consists of 26 customers, then cluster two consists of 9 customers, and cluster 3 , which consists of 15 customers.

Number of Cases in each
Cluster
\begin{tabular}{|ll|r|}
\hline Cluster & 1 & 26.000 \\
& 2 & 9.000 \\
& 3 & 15.000 \\
Valid & & 50.000 \\
Missing & & .000 \\
\hline
\end{tabular}

Figure 5. Number of Cases in each Cluster

In addition, the results are also obtained in the form of a dendrogram diagram which shows that the merging of each cluster member is based on the closest distance, thus forming a massive cluster (see Figure 6). The formation of the number of clusters is formed by the cut-off method on the dendrogram diagram. The cut-off is done at number 17 so that the clusters formed are 3 clusters with two outliers.

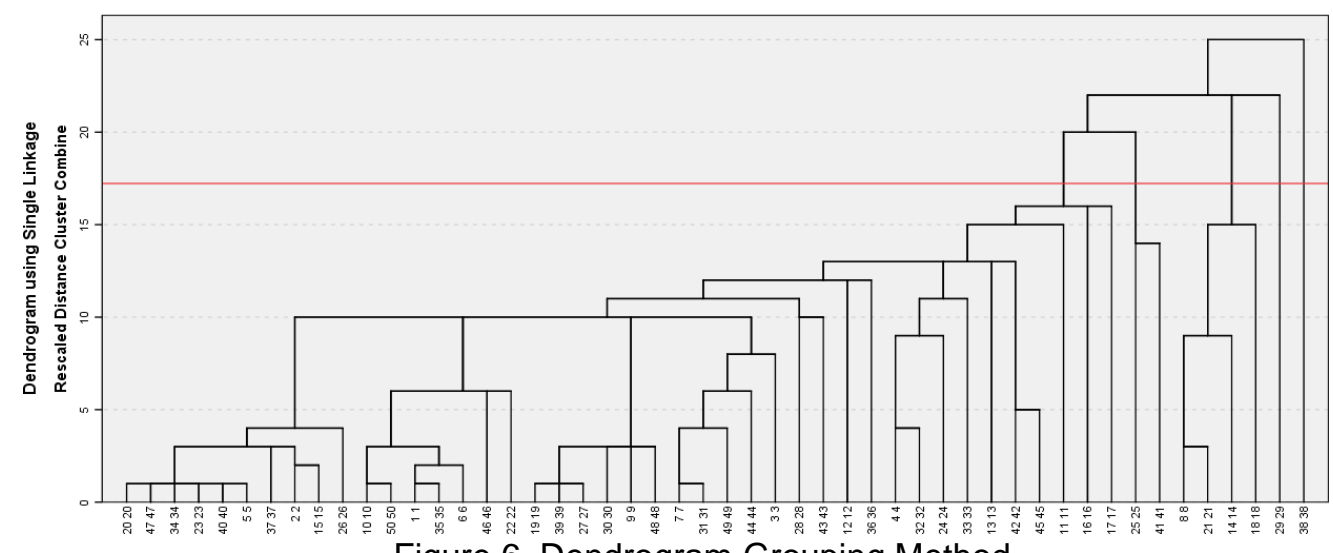

Figure 6. Dendrogram Grouping Method

Based on the results of clustering the clusters that have been obtained, it can be seen the characteristics of each cluster using the arrow similarity method. The characteristics of each cluster can be seen in Table 1 with the following explanation:

a. Cluster 1: Has one thing in common, so that it is a potential marketing target group.

b. Cluster 2: Has one thing in common, so that it is a potential marketing target group.

c. Cluster 3: Has three things in common, so it is a very potent marketing target group. 
Table 1. Cluster Characteristics

\begin{tabular}{|lc|c|c|c|}
\hline \multicolumn{1}{|c|}{ Factor } & \multicolumn{1}{c|}{ CL1 } & CL2 & CL3 \\
\hline Age & $\uparrow$ & $\downarrow$ & $\uparrow$ & $\uparrow$ \\
\hline Arrival Intensity & $\uparrow$ & $\downarrow$ & $\downarrow$ & $\uparrow$ \\
\hline Income & $\downarrow$ & $\downarrow$ & $\uparrow$ & $\downarrow$ \\
\hline Number of Similarities & 1 & 1 & 3 \\
\hline
\end{tabular}

\subsection{Association Rule \& Market Basket Analysis (AR-MBA)}

In data processing the AR-MBA method, it is necessary to group the departments first. The departmental groupings are presented in Table 2.

Table 2. Department Grouping

\begin{tabular}{|l|l|}
\hline \multicolumn{1}{|c|}{ Department } & \multicolumn{1}{c|}{ Goods } \\
\hline $\begin{array}{l}\text { Dept 1 (Household } \\
\text { appliances) }\end{array}$ & Bucket, Dipper, Plastic, Trash Can, Plastic Basket \\
\hline Dept 2 (Herbs) & $\begin{array}{l}\text { Indofood Instant Seasoning, Koepoe-Koepoe Instant Seasoning, Bango } \\
\text { Soy Sauce, ABC Soy Sauce, ABC Chili Sauce, ABC Tomato Sauce }\end{array}$ \\
\hline Dept 3 (Food) & $\begin{array}{l}\text { Champ, Pronas Corn Beef, Sanco, Segitiga Biru, Egg, Kraft, Forvita, } \\
\text { Maknyuss Rice, Sedap Noodle, Indomie Noodle }\end{array}$ \\
\hline Dept 4 (Sachet Drink) & ABC Coffee, Luwak White Coffee, Sariwangi, Poci, GreenTea \\
\hline Dept 5 (Snack) & $\begin{array}{l}\text { Sariroti, Roma, Tango, HappyTos, Pocky, Citato, Goodtime, Oreo, Taro, } \\
\text { Selamat }\end{array}$ \\
\hline Dept 6 (Milk \& Yoghurt) & Indomilk, Yakult, Frisian Flag, Ultra Milk \\
\hline $\begin{array}{l}\text { Dept 7 (Flavored } \\
\text { Drinks \& Mineral } \\
\text { Water) }\end{array}$ & $\begin{array}{l}\text { Frestea, Cocacola, Sosro, Goodday, NuGreenTea, FruitTea, } \\
\text { Javana, Nescafe, Pulpy, Teh Kotak, Pocari, You C1000, Kratingdaeng }\end{array}$ \\
\hline $\begin{array}{l}\text { Dept 8 (Grooming \& } \\
\text { Laundry Soap) }\end{array}$ & $\begin{array}{l}\text { Biore, Lifeboy, Listerine, Pepsodent, Lux, Rejoice, Pantene Pantene, } \\
\text { Parfum Gatsby, Daia, Molto, Rinso, Sunlight, Axe, Vitalis, Pucelle, Rexona, } \\
\text { Nivea, Garnier }\end{array}$ \\
\hline $\begin{array}{l}\text { Dept 9 (Skincare \& } \\
\text { Make up) }\end{array}$ & $\begin{array}{l}\text { Face Tonic Viva, Milk Cleanser Viva, Sariayu, Marck's, Lip Ice, Lip Tint, } \\
\text { Miranda, Elips, Gatsby, Vaseline }\end{array}$ \\
\hline $\begin{array}{l}\text { Dept 10 (Women \& } \\
\text { Baby Care) }\end{array}$ & $\begin{array}{l}\text { Charm, Laurier, Mamypoko, Sweety, Merries, Paseo Tissue, Nice Tissue, } \\
\text { Selection Cotton }\end{array}$ \\
\hline $\begin{array}{l}\text { Dept 11 (Gallons of } \\
\text { Gas \& Minerals) }\end{array}$ & LPG, Bright gas, Aqua Gallon, Cleo Gallon, Vit Gallon \\
\hline $\begin{array}{l}\text { Dept 12 (Cigarette } \\
\text { Equipment) }\end{array}$ & \begin{tabular}{l} 
Sampoerna, Malboro, Dunhill, Djarum, Lighter, Ashtray \\
\hline
\end{tabular} \\
\hline
\end{tabular}

After grouping the departments, we use Rapid Miner software to process the existing data (items purchased by the customer). From the results of data processing using Rapid Miner software which can be seen in Figure 7, it can be seen that the results are all valid because the lift is $>1$. In addition, it can also be seen the ranking arrangement from the best to the worst rule 
(seen from the most significant confidence value). The ranking arrangement from the best to the worst rule is as follows:

1. Purchase of goods from department 2 together with department 3 has a confidence level of $60 \%$, and a support value of $12 \%$ of the total data, and the value of the lift is 1.765

2. Purchase of goods from department 8 together with department 5 has a confidence level of $42.9 \%$, and a support value of $12 \%$ from the total data, and the lift value is 1.531

3. Purchase of goods from department 5 together with department 8 has a confidence level of $42.9 \%$, and a support value of $12 \%$ from the total data, and the lift value is 1.531

4. Purchase of goods from department 7 together with department 11 has a confidence level of $40 \%$, and a support value of $8 \%$ of the total data, and the value of the lift is 1.818

5. Purchase of goods from department 10 together with department 5 has a confidence level of $40 \%$, and a support value of $8 \%$ of the total data, and the lift value is 1.429

6. Purchasing goods from department 10 together with department 9 has a $40 \%$ confidence level, and a support value of $8 \%$ of the total data, and the lift value is 1.333

7. Purchase of goods from department 11 together with department 7 has a confidence level of $36.4 \%$, and a support value of $8 \%$ of the total data, and the value of the lift is 1.818

8. Purchase of goods from department 8 together with department 3 has a confidence level of $35.7 \%$, and a support value of $10 \%$ from the total data, and the lift value is 1.050

9. Purchases of goods from department 3 together with department 2 have a $35.3 \%$ confidence level, and a support value of $12 \%$ from the total data, and the lift value is 1.765 .

\begin{tabular}{|l|l|l|l|l|l|l|l|l|l|}
\hline No. & Premi... & Conclu... & Sup... & Confi... & LaPI... & Gain & p-s & Lift & Convicti... \\
\hline 1 & DEPT 3 & DEPT 2 & 0.120 & 0.353 & 0.836 & -0.560 & 0.052 & 1.765 & 1.236 \\
\hline 2 & DEPT 8 & DEPT 3 & 0.100 & 0.357 & 0.859 & -0.460 & 0.005 & 1.050 & 1.027 \\
\hline 3 & DEPT 11 & DEPT 7 & 0.080 & 0.364 & 0.885 & -0.360 & 0.036 & 1.818 & 1.257 \\
\hline 4 & DEPT 10 & DEPT 9 & 0.080 & 0.400 & 0.900 & -0.320 & 0.020 & 1.333 & 1.167 \\
\hline 5 & DEPT 10 & DEPT 5 & 0.080 & 0.400 & 0.900 & -0.320 & 0.024 & 1.429 & 1.200 \\
\hline 6 & DEPT 7 & DEPT 11 & 0.080 & 0.400 & 0.900 & -0.320 & 0.036 & 1.818 & 1.300 \\
\hline 7 & DEPT 8 & DEPT 5 & 0.120 & 0.429 & 0.875 & -0.440 & 0.042 & 1.531 & 1.260 \\
\hline 8 & DEPT 5 & DEPT 8 & 0.120 & 0.429 & 0.875 & -0.440 & 0.042 & 1.531 & 1.260 \\
\hline 9 & DEPT 2 & DEPT 3 & 0.120 & 0.600 & 0.933 & -0.280 & 0.052 & 1.765 & 1.650 \\
\hline
\end{tabular}

Figure 7. Rapid Miner AR-MBA Output

\subsection{Marketing Strategy}

After getting information from the data processing results above, the next step is to determine the right marketing strategy for Setia Store. The marketing strategy is to create a buy 1 get 1 promo banner or label on rarely purchased products, such as department 1 products (see Figure 8). Finally, improve the layout by uniting departments or products that are often purchased together (Laboratory of Statistics and Industrial Optimization FTI UII, 2019). Here are the banner designs, labels, catalogs, and layouts proposed by the researchers: 


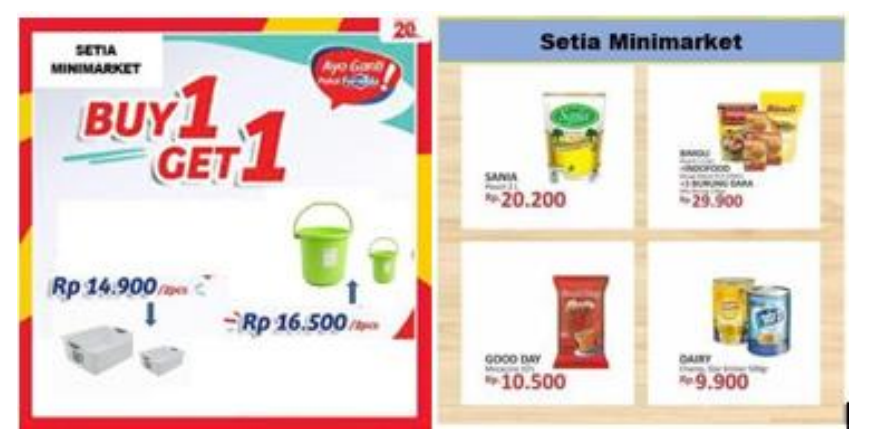

Figure 8. Promotional Labels and Product Catalogs

The difference between the initial layout and the layout proposed by the researcher is that there is a change in the position of all departments as presented in Figure 9. First, Department 11 positions were swapped for Department 1. Second, Department 5 positions were swapped for Department 3. Third, Department 3 positions were swapped for Department 5. Fourth, Department 6 positions were swapped for Department 7. Fifth, Department 10 positions were swapped for Department 8. Sixth, Department 4 positions were swapped for Department 9. Seventh, Department 9 positions were swapped for Department 4. Eighth, Department 8 positions were swapped for Department 6. Ninth, Department 1 positions were swapped for Department 11. Finally, Department 7 positions were swapped for Department 10.

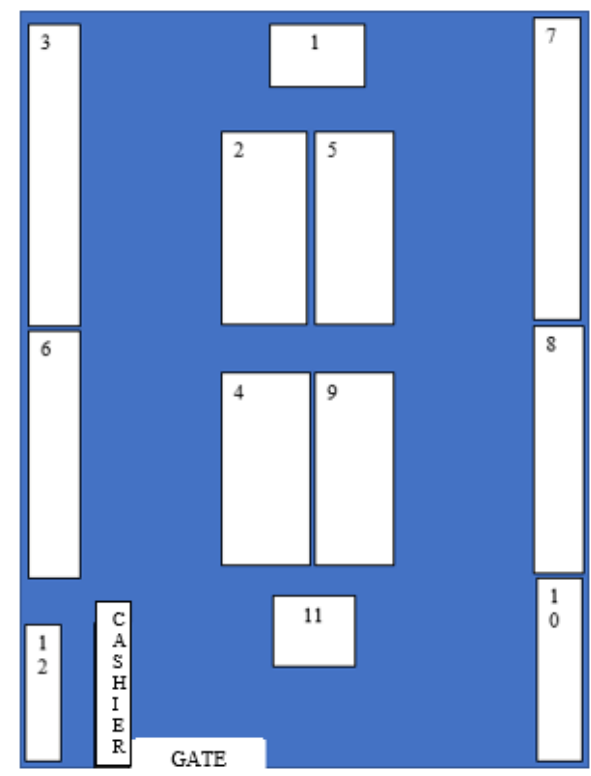

Figure 9. Proposed Layout

For information, to find out these products are rarely, often, and very often purchased. The right product or department placement can be seen and is based on the confidence value, support value, and lift value obtained from data processing results with the AR-MBA method using Rapid Miner software. 
The benefit of this marketing strategy is to provide convenience and comfort to Setia Store customers. This convenience and comfort are in approaching product layouts based on customer habits in buying products. This allows customers to buy the product they are looking for and other products that are arranged close together at the same time (Alfiqra \& Alfizi, 2018). Then, the purpose of bundling on labels or catalogs is to increase sales (Kuswayati \& Tjahyadi, 2017). Finally, providing knowledge to the general public, small business or retail owners, and further researchers that these three methods can be combined and produce marketing strategies that are more targeted. It is hoped that this research can help business owners or small retailers develop and provide the latest research references that future researchers can develop even better.

\section{Conclusion}

The AHP method is used to find the main priority of Setia Store customers. Then, the clustering method is used to find potential target markets that have similar characteristics to the results of the AHP method. Third, the AR-MBA method is used to find the best rules of product marketing.

From the results of the AHP method, the most significant Eugen vector value is 0.6270 in the type of work of housewives. This means that housewives are the main priority for Setia Store customers. Then, the results of the clustering method show that cluster 3 is a very potent marketing target because it has many similarities with actual conditions and existing factors. Finally, the results of the AR-MBA analysis show the best rule, that product purchases from department 2 along with department 3 are the most and highest, this is supported by a $60 \%$ confidence level and a support value of $12 \%$ of the total data and is valid with a lift value of 1.765 (lift > 1).

Based on the research results above, the right marketing strategy used by Setia Store is to create a banner in front of the store or a buy 1 get 1 promo label on products that are rarely purchased, such as department 1 products, household appliances. Then create a catalog by bringing together products often bought together, such as department 2 and department 3 products, spices, and food ingredients. Finally, improve the layout by bringing the departmental shelves closer to frequently purchased products.

Finally, from the results of this study, it can be seen that these three methods can be used to analyze the right marketing strategy. Then, it can be seen that these three methods are interconnected, complementary, and mutually reinforcing each other's results. Thus, the results of this study are more accurate than previous studies, which only used one or two methods. This can be seen from the way this research works, first looking for the target market, then finding and determining the best marketing treatment according to the target market's characteristics. It is hoped that this research will help business owners or small retailers to develop and provide the latest research references to future researchers so that they can be developed even better.

\section{References}

Alfiqra, \& Khasanah, A. U. (2020). Implementation of Market Basket Analysis based on Overall Variability of Association Rule (OCVR) on Product Marketing Strategy. IOP Conference Series: Materials Science and Engineering 722, 1-9. 
Alfiqra, A., \& Alfizi, F. Y. (2018). Penerapan Market Basket Analysis Menggunakan Proses KDD (Knowledge Discovery in Database) Sebagai Strategi Penjualan Produk Swalayan (Studi Kasus: Swalayan X). Industrial Engineering National Conference (IENACO). Surakarta.

Alsamaray, H. S. (2017). AHP as Multi-criteria Decision Making Technique, Empirical Study in Cooperative Learning at Gulf University. European Scientific Journal, 13(13), 272-289.

Anjassari, D. (2018). Analisis Pola Pembelian Pelanggan Pada Transaksi Pejualan. Universitas Kristen Satya Wacana.

Atmoko, T. P. (2018). Strategi Pemasaran untuk Meningkatkan Volume Penjualan di Cavinton Hotel Yogyakarta. Journal of Indonesian Tourism, Hospitality and Recreation, 1(2). 83-96.

Bastian, A., Sujadi, H., \& Febrianto, G. (2018). Penerapan Algoritma K-Means Clustering Analysis pada Penyakit Menular Manusia (Studi Kasus Kabupaten Majalengka). Jurnal Sistem Informasi, 9(1), 26-36.

Butar-Butar, D. A., Amalia, D., Trio, K. M., \& Naibaho, Y. (2020). Pemanfaatan Teknologi Informasi Dalam Pengambilan KeputusanPenilaian Karyawan Terbaik. Jurnal Sains dan Teknologi (SAINTEK), 2(1), 43-46.

Cahyono, P. (2016). Implementasi Strategi Pemasaran Dengan Menggunakan Metode SWOT Dalam Upaya Meningkatkan Penjualan Produk Jasa Asuransi Kecelakaan dan Kematian Pada PT. Prudential Cabang Lamongan. Jurnal Penelitian IImu Manajemen, 1(2). 129-138.

Diwayana Putri Nasution, S. M., \& Annisa Ilmi Faried Lubis, S. M. (2018). Peranan UKM Terhadap Pertumbuhan Ekonomi di Indonesia. Jurnal Kajian Ekonomi dan Kebijakan Publik, 3(2), 58-66.

Fawaid, A., Suharyono, \& Mawardi, M. K. (2016). Analisis Strategi Pemasaran Perusahaan yang Berorientasi Ekspor dalam Peningkatan Volume Penjualan (Studi pada PT Kharisma Rotan Mandiri di Sukoharjo). Jurnal Administrasi Bisnis, 39(1), 1-8.

Hakim, M. L. (2020). Pengelompokan Data Transaksi Penjualan Menggunakan Algoritma Clustering K-Means pada Toko An Nur. Universitas Semarang.

Halim, R., Amroni, \& Jusia, P. A. (2017). Perancangan Market Basket Analysis MenggunakanAssociation Rule untuk Pendukung KeputusanPromosi pada Sistem Penjualan Sun Young Cell. Jurnal PROCESSOR, 12(1), 964-973.

Husna, F. D. (2019). Analisis Strategi Pemasaran dalam Upaya Meningkatkan Penjualan Ikan Salai Patin menggunakan Metode AHP dan SWOT (Studi Kasus: Kelompok Pengolah Putra Agung). UIN Suska Riau. 
Ji, Z., Pi, H., Wei, W., Xiong, B., Wozniak, M., \& Damasevicius, R. (2019). Recommendation Based on Review Texts and Social Communities: A Hybrid Model. IEEE Access, VII, 4041640427.

Keputusan Presiden (KEPPRES) NO. 99, LN. 1998 NO. 112, LL SETNEG : 21 HLM. (n.d.).

Kuswayati, S., \& Tjahyadi, D. (2017). Market Basket Analysis Menggunakan Algoritma Apriori untuk Penetapan Strategi Bundling Penjualan Barang. Jurnal STT Bandung, 5.

Laboratorium Statistika dan Optimasi Industri FTI UII. (2019). Modul Association Rule. Yogyakarta: FTI UII.

Lestari, D. R. (2019). Implementasi Data Mining Untuk Pengaturan Layout Swalayan Delimas Lestari Kencana Dengan Menggunakan Dengan Menggunakan Algoritma K-Means Clustering. Jurnal Riset Komputer (JURIKOM), 6(2), 112-117.

Mohammad, G. (2018). Penilaian dan Perbaikan Performansi Rantai Pasok Menggunakan Supply Chain Operation Reference (SCOR) untuk Divisi Grocery di Super Indo Supermarket Cabang Istana Majapahit Semarang. Universitas Islam Indonesia.

Munthafa, A. E., \& Mubarok, H. (2017). Penerapan Metode Analytical Hierarchy Process dalam Sistem Pendukung Keputusan Penentuan Mahasiswa Berprestasi. Jurnal Siliwangi, 3(2), 192201.

Nagari, S. S., \& Inayati, L. (2020). Implementation of Clustering Using K-Means Method to Determine Nutritional Status. Jurnal Biometrika dan Kependudukan, 9(1), 62-68.

Nurainun, T., \& Malva, Y. A. (2016). Rancangan Strategi Pemasaran Menggunakan Metode AHP dan Marketing Mix (Studi Kasus PT. XXX Pekanbaru). Prosiding Seminar Nasional XI "Rekayasa Teknologi Industri dan Informasi". Yogyakarta.

Permata, E. G., Kusumanto, I., Nur, M., \& Sijabat, M. N. (2019). Analisis Strategi Pemasaran Dengan Menggunakan Metode Swot dan Analytical Hierarchy Process(AHP) untuk Meningkatkan Volume Penjualan. Seminar Nasional Teknologi Informasi, Komunikasi dan Industri (SNTIKI) 11. Pekanbaru.

Riandi, T. (2021). Analisis Strategi Pemasaran untuk Meningkatkan Kinerja Perusahaan pada Perusahaan Batik Tasik Indah. Universitas Siliwangi.

Rosiska, E., \& Harman, R. (2019). Metode Analitical Hierarchy Process (AHP) Dalam Pemilihan Umum Presiden Indonesia 2019. Jurnal Nasional Informatika dan Teknologi Jaringan, 3(2), 297-306. 
Sari, H., \& Nurhadi, D. A. (2019). Designing Marketing Strategy Based on Value from Clothingproducing Companies using the AHP and Delphi Methods. Jurnal Teknik Industri, 20(2), 191203.

Shi, Y., Wu, B., Chen, N., \& Chen, A. (2019). Determination of Effective Management Strategies for Scenic Area Emergencies Using Association Rule Mining. International Journal of Disaster Risk Reduction, 39, 1-10.

Taherdoost, H. (2017). Decision Making Using the Analytic Hierarchy Process (AHP); A Step by Step Approach. International Journal of Economics and Management Systems 2, 244-247.

Tatiana, K., \& Mikhail, M. (2018). Market Basket Analysis of Heterogeneous Data Sources for Recommendation System Improvement. Procedia Computer Science, 136, 246-254.

Xiao-yu, L., Li-ying, Y., Hang, L., \& Xue-fei, T. (2017). The Parallel Implementation and Application of an Improved K-means Algorithm. Journal of University of Electronic Science and Technology of China, 46(1), 61-68. 
This page is intentionally left blank. 